\title{
INCIDÊNCIA DE BIPOLARIS SOROKINIANA NAS SEMENTES E A TRANSMISSÃO PARA PLANTAS DE CEVADA
}

\section{BIPOLARIS SOROKJNIANA INCIDENCE IN SEEDS AND TRANSMISSION TO BARLEY PLANTS}

\author{
Josiane Takassaki Ferrari \\ Orintador: Prof. Dr. Edilberto Possamai
}

\begin{abstract}
RESUMO
O potencial de rendimento do cultivo de cevada é diminuído principalmente pela ocorrência de doenças como helmintosporiose ou mancha marrom (Bipolaris sorokiniana Sacc. in Soroc) transmitida pelas sementes. A hipótese desse trabalho é de que se a semente de cevada é o principal agente de disseminação de Bipolaris sorokiniana, então diferentes níveis de incidência do fungo em sementes podem se correlacionar com a incidência do fungo nas plantas oriundas dessas sementes. $O$ objetivo desse trabalho foi verificar a correlação entre diferentes níveis de incidência do fungo em sementes e sua transmissão para plantas de cevada em campo e casa-de-vegetação e determinar a capacidade de transmissão do fungo pela semente. Sementes de vários lotes da cultivar BR2 com níveis de incidência de 2,7; 7,5; 12,5; 16,5; 31,0 e 55,5\% foram semeadas em campo com 4 repetições. As avaliações foram realizadas aos 7 dias após a emergência, nas 4 fileiras centrais de cada parcela, contando-se o número de plantas com sintomas de helmintosporiose e determinando-se a porcentagem em relação à emergência. Em casa-de-vegetação as sementes foram semeadas em caixas plásticas com aproximadamente $13 \mathrm{~kg}$ de solo esterilizado com dazomet. Foram utilizadas 400 sementes a profundidade de $3 \mathrm{~cm}$. Demonstrouse a importância da semente infectada como fonte de inóculo primário. Observou-se que a transmissão do patógeno no campo foi mais eficiente quando o nível foi de 55,5\%. Em casa-de-vegetação, houve correlação apenas entre a incidência nas sementes e nas raízes. Conclui-se que não há correlação entre diferentes níveis $\mathrm{B}$. sorokiniana nas sementes e a sua incidência em campo e que níveis de $55,5 \%$ diminuem a emergência das plantas no campo e em casa-de-vegetação.
\end{abstract}

\begin{abstract}
The yield potential of barley is reduced mainly because of diseases such as helminthosporiosis or spot blotch caused by Bipolaris sorokiniana (Sacc. in Soroc.) which is seed transmitted. The hypothesis of this study is that the seed is the principal means of disease dissemination and thus, different levels of the fungus incidence in seeds could be related with its incidence on plants originated from those seeds. The objectives of the work were: to study the correlation among different levels of seed infection and its transmission to barley plants under field and greenhouse conditions, and determine the capacity of seed transmission of the fungus. Barley seeds $\mathrm{cv}$ 'BR-2' naturally infected with the levels of $2.7 ; 7.5 ; 12.5 ; 16.5 ; 31.0$ and $55.5 \%$ of the fungus were sown in the field, with four replications. The evaluation of disease seedling showing symptoms of helminthosporiosis and its percentage in relation to the seed emergence, were made seven days after emergence. In greenhouse, seeds were sown in plastic trays containing with approximately $13 \mathrm{~kg}$ of soil previously sterilized with dazomet. Four hundred seeds of each treatment (infection level) were planted and covered with $3 \mathrm{~cm}$ of soil ( $3 \mathrm{~cm}$ depth). The importance of the infected seeds as a source of primary inoculum was demonstrated. It was observed that on the field the transmission of the pathogen was more efficient when the seed infection level was $55 \%$. On the other hand, in greenhouse there was correlation only between seed infection and roots. In conclusion, there was no correlation among the seed infection levels of B. sorokiniana and their incidence in the field, and seed infection levels of $55 \%$ reduce seedling emergence both, in the field or in greenhouse. Key-words: seed transmission, spot blotch, seed infection, seedling emergence.
\end{abstract}

